\title{
Comparison Between Rubens and Rembrandt's Creative Thoughts
}

\author{
Weihong Yan \\ Luoyang Normal University \\ Luoyang, China
}

\begin{abstract}
Nederland was divided into southern Flanders and the northern Holland Republic for religious reform. When they were united in the past, they only had one national spirit. After splitting and opposing, there were two national spirits. People in the two regions held different outlooks on life, thus producing different painting schools. The transformation of the political situation has also led to the transformation of thoughts and feelings. The political storm has not only split the country, but also split the art. Rubens and Rembrandt, as representative painters of the North and South after the split of Nederland, their creative ideas represent the differences in religious beliefs between the North and the South. This article details the influence of religion on the art of North and South and how it is reflected in the artist's creative thinking.
\end{abstract}

Keywords—religious reform; Rubens; Rembrandt; creative thought

\section{INTRODUCTION}

With the widespread and deepening of the religious reform movement in Europe, in 1566, the people of Nederland started the Bourgeois Revolution against Spain's feudal autocratic rule and striving for national independence by destroying the Holy Image. Later, the northern provinces of Holland, through this revolution, established the Commonwealth of the Republic and gained independence. Southern Flanders, under the leadership of the Spanish Grand Princess Archdukess Isabella and her husband, Austrian Archduke Albert, was once nominally a "Nederland Independent State" (1599-1633), actually still affiliated with Spain. Since then, the lowland countries of Nederland have effectively divided into two parts: the one is the Catholic Spanish-affiliated Flanders in the south, and the other is Protestant republican government of the Netherlands in the north.

The Flemish and Dutch schools after the split have many differences in art.

\section{COMPARISON OF THE SERVICE OBJECTS AND LANGUAGE STYLES BETWEEN FLEMISH SCHOOL AND DUTCH SCHOOL}

The Flemish School of Painting mainly serves the courts, churches and nobles with Catholic faith, and is dominated by Baroque art. At that time, the patrons of the paintings are mostly the luxurious royal princes, the aristocratic bourgeoisie and the Catholic Society of Jesus and other Christian Unit. Catholics like to decorate churches and use music and ceremonies to enhance their faith, which leads to the development of the palatial baroque style in Flanders Catholic believers believe that the artwork itself is a representation of God's goodwill, which inspires and helps the faith. Rubens uses his genius to promote the faith of believers, and is committed to infusing his beliefs and painting skills into how humans are liberated from the flesh. Aesthetic appreciation and religious sentiment are closely integrated.

In terms of artistic form language and style, Flanders mainly learns from Italy. Rubens once studied in Italy for eight years and was deeply influenced by Italy's artistic interest. In his paintings, Michelangelo's strength and grandeur, Venetian brilliance and gorgeousness, and the clarity as well as smoothness of the Nederland tradition are cleverly blended together and reach the acme. He expresses the Baroque style of this era in a subtle painting language, such as strong movements, exaggerated forms, unrestrained emotions, far-reaching space, and luxurious decorative features. At the same time, he also injects Catholic humanism into his own works. This kind of humanism allows the pleasure of the senses to develop in parallel with the sense of religion, thus creating an optimistic, refined and energetic style.

The political climate and social structure of the North Holland is completely different from Flanders. In the Holland, the boring and complicated ceremony of the Archbishop is abandoned, and the statues of Jesus Christ and the Virgin in the church are dismantled; the religious themed murals symbolizing idol worship are erased, the walls are repainted into white ash; the apostles' relics are buried; the organ and rituals in the church are all removed; the clergy, monks, nuns leave the monastery and get married; the monastery property is confiscated or sold for the establishment of schools. In the Northern Netherlands, the Protestant Church is completely separated from the Catholic Church and is managed by pastors elected by the parishioners. Calvin builds the church into a clean and economical church needed by the emerging bourgeoisie.

The Dutch School of Painting is mainly aimed at the emerging bourgeoisie, merchants and citizens, mainly inheriting the tradition of the Nederland realism. Dutch people living in the North love working, thrifty, comfortable 
and tidy living environment, and affectionate family atmosphere, so that Baroque luxury scenes fail to interest them. In response, portraits, altars and fine paintings serving Catholicism has lost their appeal to Protestants. Most of the power and wealth are in the hands of the public. It is the shipbuilders, evangelists, doctors, businessmen and bankers who have built most beautiful new houses and hope to decorate their new homes with paintings and hope for themselves drawn. They are the first visual evidence of bourgeois democracy. They are passionate about expressing their self-esteem and self-confidence, portraying people's lives and feelings, and praising the beauty and tranquility of nature. Portraits, still life, and landscape paintings have become the main kinds of Dutch paintings. Paintings begin to re-emphasize realism, focusing on simple everyday things and simple emotions. Rembrandt's artistic activities are carried out under such social and historical conditions. If it is inevitably influenced by the Baroque art style that is popular throughout Europe, at least in Rembrandt's paintings, the Baroque factors can only be in a secondary position compared to the humanistic light of religious care. Therefore, although Rembrandt belongs to the Baroque art era in time, he is undoubtedly a great realist master.

\section{COMPARISON OF RUBENS AND REMBRANDT'S CREATIVE THOUGHTS AND STYLES}

It's hard to imagine that Rubens and Rembrandt are contemporaries. Both two people live in the first half of the 17 th century in the lowland country of Nederland, with the exception that Rubens is in Antwerp in Flanders and Rembrandt is in Amsterdam in the north of the Netherlands. Rubens seems to belong to a more ancient era with more classical and international style; Rembrandt shows more of his characteristics as a Dutchman. His inspiration mainly comes from his own interpretation of the ancient Bible, not references to classicality.

Born in the upper class, Rubens inherits the advantages of his parents: the mother's generous and elegant character, love of life, the ruly use of time and money; and his witty and kind personality, gentility, generosity, sharp-mind, politically understanding, ability to maintain good relations with clients and sponsors come from his father, once a lawyer and local official..

Because of his talent in painting, elegant manners and amazing linguistic talent, proficient in French, German, Italian, Latin and Spanish, Rubens is able to reach the elites of the European countries as diplomatic envoys, and his aesthetic taste is bound to be influenced by this group of people. Rubens's works generally have grand scenes, strong sense of movement, dramatic plots, contrasting and loud colors, and smooth lines and large strokes suitable for his lively contents and rhythm of movement, resulting in pictures of gorgeous and fiery effect, and cause a festive atmosphere of joy, winning the appreciation of the princes and wealthy businessmen. He studies under the Oto vanVen, a member of the "Roman-style" elite society at that time, and learns the initial techniques of painting, but his true teacher is masterpieces of the masters of successive generations in the museums of Italy and other places. Rubens once traveled to Italy thoroughly for eight years and served as the court painter of the Duke of Mantua, Italy. During that time, he meticulously explored the fine works of the Italian Renaissance masters, studied the sketches of the two factions of Florence and the powerful expression of the human body, and dramatic movements rhythm and magnificent colors of the two parties of Venice. In the meantime, he was influenced by the Roman Baroque art style that was popular in Italy. Moreover, he noticed the secular tendency of the Caravaggio School and the shading techniques in its paintings. But Rubens still pays attention to the tradition of Flemish art. What is commendable is that he has created his own unique artistic style based on the strength of each school.

Rubens's religious themed paintings follow and carry forward the Italian tradition, tending to a bold and huge proportion and grand theme, forming a style that is both Catholic and pagan. His works sing "human" and "nature" instead of God, focusing on the expression of vitality and passion. The Christian meaning of its religious works is limited to the title and all mysterious or abstinence consciousness is abandoned. The painting of the Virgin, the Martyr, the Confessor, Christ, and the Apostles are all confined to the body of the real life, and all the ancient gods resurrect in the palaces of the princes and kings with real names, because for Flanders, religion is mainly about rituals just like Italy. Rubens looks at Mass every morning and donates paintings to the church to make up for the sins. Then he still holds the poet's point of view on the secular, and paints the fleshy goddess as well as the sea banshee in the same style. Although his painting is coated with a layer of Catholic oil paint, the customs, habits, feelings and thoughts in the bones are all pagan. He put the figure in the emblem together with the real person, the cardinal with the naked god, showing all the instincts of animals in human nature. His characters seem to be speaking. Beyond the face, the whole posture shows the fluctuation of thought, enthusiasm and life, the elusive expression, the softness and elasticity of the bloody flesh, and no one knows more deeply about the physiological changes and physical life.

However, Rubens lacks subtle observation, and most of his characters lack personality and connotation. Whether they are princes, nobles or Virgin Mother and saints, they are equally luxurious and difficult to transcend ordinary and vulgar. His strength lies in the keen sense of color, the simple ups and downs of composition, and the expressiveness of lines. However, he does not have the artistic skills to express real emotions. He cannot grasp the psychology and emotions of the subject with strong personality and accurate observation. It is this that makes Rubens unable to gain the spirituality of the art like Rembrandt.

Unlike Rubens, Rembrandt was born in a Dutch miller's house, sincerely and reluctantly, showing the wildness and rebellion that refused to stick to the rules. Both his grandfather and father participated in the anti-Spanish war of independence, which led him to be influenced by progressive thoughts and love freedom and independence. He once said: "what more important than money is reputation and more important than the reputation is freedom. The ups and downs 
of fate do not make his creation decline, but instead makes his artistic pursuit more independent and independent; the poverty of life is not enough to make him please the upper class. Instead, he makes a deeper understanding of the social contradictions in the Netherlands in the mid-17th century, thus stimulating a high degree of democratic and humanitarian spirit. He demonstrates this unshakable belief with his artistic creation throughout the life. As an artist, he is both sensual and mysterious, both a realist and a dreamer. He tries all his best to express what the painting seems to be unable to express, namely the inner world of human.

Rembrandt's artistic path is neither Baroque nor Classical, but belongs to Caravaggioism with Dutch characteristics. He is a great realist painter of the 17 th century, walking an independent art path. It is manifested in the following aspects: First, the life of the work. No matter what the subject matter or characters, they are drawn from the perspective of life. In his painting, heroes, Virgins, are all people in life; second, times and socialization. His works are full of the atmosphere of the times and social characteristics; the third is nonreligious. Although he paints many religious works, but no one is to promote religion, instead to promote the goodness of human nature and yearning for a better life often by means of religious themes. He blends the spirit of Christ with humanitarianism; fourth, his art has a certain critical feature, which makes him a little out of step with the society at the time. Because of his unfortunate experience (especially his later life), he creates some tragic works. Unlike most painters in the Netherlands, he is the most sober realist who never yields and caters to the tastes and requirements of the subscribers; fifth, he has a unique contribution to portraits. His portraits not only depict a person, but also depict a society, an era, and a mirror of the times and society. Here, it is a tortuous reflection of human destiny, human suffering and joy; the sixth is the achievement in skill and technique. $\mathrm{He}$ is good at styling with light. His paintings often do not have a clear outline, but use a method of contrast between light and dark to create a three-dimensional sense of the character, highlighting the position of the character in space. The changes in light and color are very complicated and subtle, and they play a unified and coordinated role in the picture.

In fact, Rembrandt is a unique religious painter with original spirit in the history of painting. His works are more like a history of thinking reflecting the Bible. He can understand not only the mystery and greatness of the Old Testament, but also the philanthropic spirit of the New Testament. Rembrandt reinterprets the sacred history and myth in the light of human experience. This is a reflection of feelings when revealing religious truth on the basis of faith. When his greatest contemporaries were looking for a reality built by means of knowledge, Rembrandt established a kind of psychological reality by using his true feelings, which was a psychology truth hidden in paintings that was really far more than any previous artist.

\section{CONCLUSION}

Because Rubens and Rembrandt are in the era of Western Church Reform, the source of style differences is related to their different religious beliefs and service objects to a great extent. This article compares the two people's creative thoughts, background and formal language differences with each other on the same plane, from which it can been seen more clearly that the significant influence of the times and the environment on artistic creation.

\section{REFERENCES}

[1] Philosophy of Art, [French] Danto, Fu Lei translates, Anhui Literature and Art Publishing House, the first edition of July 1991.

[2] "Religious Reform and Western Modern Social Thoughts", Li Pingye writes , China Today, the first edition of June 1992. (in Chinese)

[3] Calvin, [Germany] Michael Malay writes, Shanghai Translation Publishing House, 2001 Edition.

[4] "World Classical Artists Collection — Rubens", World Publishing Cooperation, the first edition of September 2004. (in Chinese)

[5] Art and Civilization - History of European Art and Culture, [English] Kenneth Clarke, Orient Publishing Center, the first edition of January 2001 . 